\title{
The Case of István Szabó
}

\author{
By Christina Stojanova
}

Fall 2003 Issue of KINEMA

\section{TAKING SIDES: THE CASE OF ISTVÁN SZABÓ}

THERE is a scene halfway through István Szabó's latest film, Taking Sides: The Case Furtwängler (2001, Germany-France), where the American interrogator Major Steve Arnold confronts the legendary German conductor and music director of the Berlin Philharmonic with the question why he did not leave Germany despite of his disapproval of the Nazi regime. Wilhelm Furtwängler's answer is humble and simple: because I am not Jewish and because I tried to help from inside. The crucial moral choice, involved in one's decision to leave one's country, the choice that could make or break a human being, has been one of the central themes of Szabó's oeuvre since Lovefilm (1970). A beautiful, nostalgic film about the passionate meeting in Paris of two lovers, separated by immigration for more than a decade after the bloody suppression of the Hungarian anti-Communist uprising in 1956. The same theme resurfaced again forcefully in his Oscarwinning Mephisto (1981), where the famous German actor Hendrik Höfgen (tailored after Gustaf Gründgens, a well-known inter-war German actor and Klaus Mann's brother-in-law), refuses to leave Germany at the height of Nazism as he, too, believes that there is no life for him without his art, which he can only practice in German and in Germany, where he would be more useful for his persecuted friends 'from inside'.

In Mephisto, emigration is seen as a possible salvation from a disgraceful pact with the Devil, and is interwoven in the powerful metaphor about the role of the artist under totalitarian regime. Höfgen's dilemma is as intricate as that of Dr. Faustus: is artistic freedom possible at all under the auspices of a totalitarian state, and if it is, does it not end up serving the macabre designs of the powers-that-be and ultimately destroy the artist?

Adam Sors from Sunshine (2000, Hungary-Canada-Austria) is also approached with an offer to emigrate to America as an Olympic medallist, but he indignantly rejects the proposal as demeaning for an officer in the Hungarian army. Apparently, being a Jewish-Hungarian filmmaker, Szabó himself has considered emigration as a very real option. Yet like his protagonists, he preferred to remain in his native Hungary, to work and help from inside, demythologizing the Communist totalitarian regime through the compelling Aesopean language of his films. His obsession with the crucial, even fatal role of history in one's life has shaped his artistic preferences: he projects his modern fables back in time, thus elegantly concealing the transparent contemporary edge of his metaphors, which, if told explicitly, would have inevitably provoked a censorship ban. In fact, after his first film The Age of Daydreaming (1964), Szabó has revisited contemporary reality only twice and only after the collapse of Communism. Once unsuccessfully - with Meeting Venus (1990) his first English-language film, a Euro-pudding par-excellence, failing to adjust European cultural concerns to American commercial interests, and once successfully - with Sweet Emma, Dear Böbe (1992), a poignantly pessimistic narrative about two women struggling to survive in post-Communist Budapest. All his other films - from Budapest Tales (1976) and Confidence (1979) through the Hungarian-Austrian trilogy - Mephisto (1981), Colonel Redl (1985) and Hanussen (1988), which propelled him and actor Klaus Maria Brandauer to international fame, to the opulent saga Sunshine (2000) and his latest, Taking Sides (2001) - are situated in the most dramatic period of the $20^{\text {th }}$ century European history, flanked by the Great War (1914-1918) and the Second World War (1939-1945). Albeit inspired by real-life prototypes ${ }^{(1)}$ or well-known literary works, the Mephisto trilogy ${ }^{(2)}$, Sunshine and Taking Sides could hardly be called biographical or bona fide literary adaptations. In fact, Szabó always writes his own scripts, and is credited with saying that

one should not make a film based on a really good novel, because such a novel has already found its authentic form, which is to be read. Films should be made from novels that have ... something important to be developed: a character, a story, a leitmotif, etc. ${ }^{(3)}$

His period films constitute a genre of their own, which could loosely be defined as a philosophical-ethical dialogue with history. As a true heir of European rationalism and its specifically Central-Eastern European brand, which sees the artist-intellectual as conscience of the nation and an aristocrat of the enlightened spirit, 
Szabó is passionately involved with the major ethical questions of his time. His protagonists are self-made artists or intellectuals, caught in the cobweb of history and burdened with a mission they would have hardly chosen themselves. As Szabó put it elegantly in our interview from last July, ${ }^{(4)}$

[t] here has always been this love-hate relationship between art and politics.

Politicians seduce people and need artistic talent to do so, while artists have charisma in abundance, but usually lack the means and the power to reach people. Obviously, they need each other, being at the same time envious of each other.

Therefore his protagonists are torn between their attraction to power and moral indignation with their own compromise. The dominant political force of the day, oppressive and hostile, is usually embodied by a powerful opponent who could be an aristocrat (the Crown Prince in Colonel Redl) or a high-ranking officer (The General, representing Goering, in Mephisto). And while Szabó constructs the antagonist as a complex personality, minor representatives of the regime are often one-dimensionally evil. They usually belong to what Szabó called the 'petty-minded petit-bourgeoisie', who, 'deluded in their search for stability and order', have always been the 'breeding ground of all repressive regimes'. The women and friends of the protagonist are rarely more than, in psychological terms, externalizations of his alter-ego. Thus Szabó's films function as bi-polar energy systems, where the 'truth' shifts from one pole to the other, along with the sympathies and antipathies of the viewers.

In the line of the great cinematic thinkers, he comes closest to Jean Renoir and his psychologically balanced musings on the human condition in time of crisis (The Great Illusion, 1937) and to Ingmar Bergman's metaphysical treatises on the unity of the opposites (Persona, 1968). However, in his classical preoccupation with clarity of the argument, Szabó's oeuvre is decidedly far from the paradoxical humour of the former, and from the transcendental fatalism of the latter.

If in the Mephisto trilogy this architecture of representation was a discovery, and was perfectly served by the cinematographic style of the 1980s (cameraman Lájos Koltai) - fragments, chiaroscuro lighting effects, fog and nightly shots, predominant brownish colours - in Sunshine it reaches baroque magnificence. The three-hour narrative, spanning the period from the belle époque through the collapse of Communism in 1989, follows three generations of a Hungarian-Jewish family and is loosely based on Szabó's own family history and that of the assimilated Zwacks, makers of the famous digestive herbal drink Unicum. The triptych form, tested in the Mephisto trilogy, benefits again of the casting of the same actor - Ralph Fiennes - in three different apparitions of Sonnenscheins: father, son and grandson.

The major challenge Fiennes's characters encounter is the ever-growing pressure to assimilate to be able to participate fully in the Hungarian public life. Initially, prompted by a 'suggestion' of his superiors, Judge Ignatz Sonnenschein changes his name to the more Hungarian-sounding Sors mainly as a gesture of respect for Emperor Franz Joseph's ethnic tolerance. His son, the Hungarian Army officer Adam Sors converts to Catholicism in the name of his principles and his brilliant fencing career. The pressure reaches its breaking point with the introduction of the anti-Jewish laws in 1938-1939, when neither name or loyalty nor faith and fame could save Adam and his family from the Holocaust. Adam's surviving son, Ivan Sors begins his career as a loyal Communist, member of the much-feared Secret Police. Deeply disappointed with Communism's repressive nature and unveiled anti-Semitism, however, he becomes a dissident and reclaims his old family name, Sonnenschein.

Obviously, by painting empathically three versions of yielded Jewish identity, and the ensuing tragedies, Szabó comes to terms with his own Hungarian-Jewish heritage. Ivan is the character closest to him since he lives through the times and challenges, experienced by the director himself. As a tribute to Sonnescheins' dramatic saga, Szabó concludes with Ivan's voice-over reading of Emmanuel Sonnenschein's instructive letter to his first-born son Ignatz, while the notebook with the secret herbal drink recipe disappears into the garbage truck container, thus making explicitly clear that the Sonnenscheins' most important legacy is their name and moral principles.

In Taking Sides the narrative is reduced to classical purity, predicated on the ascetic structure of the original, Ronald Harwood's play from 1995. The two protagonists, Furtwängler (Stellan Skarsgard) and Major Steve Arnold (Harvey Keitel), the accused and the accuser, are facing each other directly, with only a couple of 
intermediary personages and no parallel action. The presence of history is made palpable even through Lájos Koltai's tight classical shots of a few, but very expressive scenes of rubble-strewn Berlin from 1946, and by the introductory excerpts from rarely seen American army propaganda reels.

Brandauer's protean personages allowed Szabó to involve the viewers in his own philosophical dialogue with history and to share his ethical qualms. In psychoanalytical terms, the ultimate demise of Mephisto, Redl and Hanussen could be seen as Szabó's attempts at exorcising his own angst of a privileged artist-intellectual, working under a repressive regime, by exposing the dark side or the 'shadow' (in Jung's terms) of artistic success (or any public success for that matter). Therefore he is more interested in the self-destructive process of compliance and collaboration, which is the only legacy of his notorious historical personages, not so much in the end result of their professional or artistic ambition, which remains dubious anyway.

In Taking Sides, on the other hand, Szabó is mainly concerned with the Furtwängler's legacy and how his alleged compliance with the Nazi elite has affected his place on the musical Olympus. We see him conducting twice: at the very beginning of the film, in a re-enactment of his famous (and recorded) concerts under the muffled sound of bombs, falling over Berlin, and at the very end, in a newsreel footage from a command performance of the Berlin Philharmonic, where he is accepting the applause of Nazi dignitaries and of Goebbels himself. Unlike the charismatic and sexually ambivalent protagonists of the Mephisto trilogy, we never see Furtwängler as a private person, but only as a subject of de-Nazification, questioned or waiting to be questioned by Major Arnold. Stellan Skarsgard, in his arguably best role so far, has limited his acting to his intense introverted gaze and scarce but meaningful gestures. His Furtwängler is not comfortable with words, which is not surprising since his medium of expression is music. It is Major Arnold, who doggedly pursues information to prove Furtwängler guilty - if not of collaboration than of compliance with a murderous regime - who does most of the talking.

Unlike the antagonists from the Mephisto trilogy, however, Furtwängler's accuser is not an aristocrat or an officer, neither politician or intellectual. Yet Szabó energetically shakes off the suggestion that he belongs to the 'petty-minded petit-bourgeoisie' stratum. In his view, the committed American, a mobilized insurance agent, who made his way through the ranks with bravery, obedience and luck, "belongs to another culture, as different from the European as the Chinese or the Indian, but original culture nonetheless." As a good soldier, he would do anything to live up to his superior's expectations and find Furtwängler guilty, as a "gifted artist who sold himself to the devil." The outraged public opinion back home needed a "high-profile, internationally renowned Nazi accomplice exposed", especially after the concentration camp horrors were becoming widely known.

What ensues is a three-part dialogue between 'the blind and the deaf', as Positif's Jean-Loup Bourget has wittingly put it. ${ }^{(5)}$ The two opponents are not simply situated on both sides of an ethical and philosophical divide, they subscribe to incompatible value systems, coming from "entirely different cultures" and even epochs. Harvey Keitel's righteous bully of a major is the perfect emissary of Pax Americana and its noble but often misguided objectives. He remains deaf not only to the beauty of Beethoven's Fifth under Furtwängler's magic baton, but also to the intricate subtleties of the politics of art under totalitarianism. Profoundly shaken by the Nazi atrocities he has witnessed on the front, in the camps and in newsreels, he judges the Furtwängler's case as a simple instance of hypocritical ambition. Anyone who had not left the country, worse: had enjoyed a prosperous career and privileged existence under the murderous regime, is guilty and has to be punished.

Furtwängler, on the other hand, is deeply frustrated and angered by Major Arnold's humiliating accusations, which seem to aggravate his personal crisis of conscience and inevitable sense of existential guilt before the evolving tragedy of his people. He is unable however to see the Major's logic: for Furtwängler, leaving his country at such a moment would have meant betrayal of those, whom he was still able to 'help from inside'. Besides, he was never a Party member, and always held onto his baton as an excuse for not giving the Hitler's salute. And, as a true European intellectual from the Romantic school, he shares the belief or, as Szabó put it, "the delusion that 'art is longer than politics' and belongs to the transcendental human spirit that could never be debased by politics."

But why Furtwängler, and why now, after his name has been overwritten many times over by that of his glorious successor, Herbert von Karajan, his worst nemesis, or 'the little k' as Furtwängler used to 
call him, who, irony of ironies, never shied away from the Hitler salute or from membership of the Nazi Party? According to Szabó, his film was prompted by the need to rebuff "numerous attempts in postCommunist Eastern and Central Europe to bring to book famous artists and intellectuals who worked during Communism." In order to "invite people not to judge the situation in black and white terms and to understand better the complexity of art and politics in a totalitarian regime", he has introduced two fictional, but very important secondary characters: Major Arnold's English-speaking secretary Emmi (Brigit Minichmayr), daughter of a German officer, executed for the failed assassination attempt on Hitler's life, and his assistant, the German-Jewish-born, American-raised Lt. David Wills (Moritz Bleibtreu). The growing affection between Emmi and David counterbalances emotionally Arnold's arrogance. They "open up the horizon of the film's philosophical and ethical arguments towards young audiences"; moreover, their generous appreciation for a great artist "ensures the continuity of Furtwängler's legacy." The legacy of a man, tragically torn between art and politics, that will linger on with one of the finest interpretations of Beethoven's Fifth.

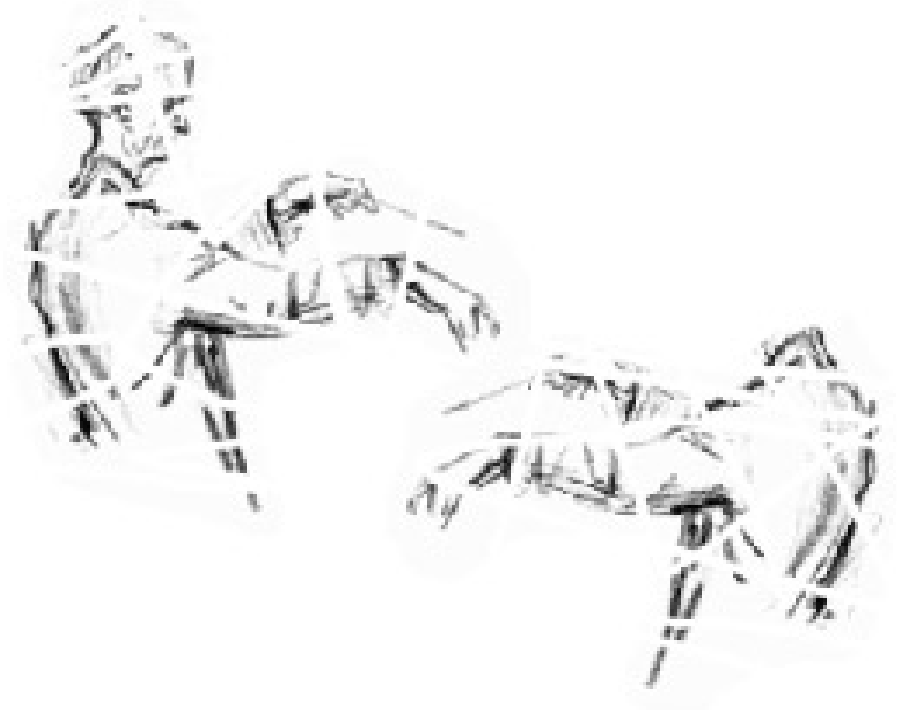

Figure 1:

\section{Notes}

1. Colonel Redl is based on the true story of man of humble origins who advances through the ranks to become head of the Emperor's military secret police only to be framed as a spy and forced to kill himself. Hanussen follows the life and times of Hitler's infamous clairvoyant, assassinated by the Gestapo after he predicted the downfall of the Third Reich.

2. Klaus Mann's novel Mephisto; John Osborne's novel A Patriot For Me!, Erik Jan Hanussen's Autobiography.

3. John W. Hughes. "Mephisto: István Szabó and 'the Gestapo of Suspicion"', Film Quarterly, Vol. 35, No. 4, Summer, 1982, p. 14.

4. At the Karlovy Vary IFF, Czech Republic.

5. Jean-Loup Bourget. "Taking Sides: le cas Furtwängler", Positif, Mai 2002, p.72. 


\section{Author Information}

Christina STOJANOVA teaches at the Department of Media Production and Studies at the University of Regina, Canada. She has contributed to Cine-bulles, KinoKultura, and the Montreal Gazette. Her publications include chapters in Berlin Culturescapes, Making it Like a Man: Canadian Masculinities, Eastern European Cinema, Traditions in World Cinema, Horror International, Alternative Europe and Cinema and Globalization. 